\title{
Results of national White Stork (Ciconia ciconia) census in Hungary in 2019
}

\author{
Péter LovÁszi*, Károly NAGY \& Zoltán GöRÖGH
}

Received: May 19, 2020 - Revised: May 27, 2020 -Accepted: May 28, 2020

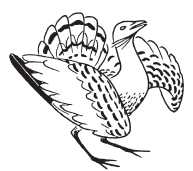

Lovászi, P., Nagy, K. \& Görögh, Z. 2020. Results of national White Stork (Ciconia ciconia) census in Hungary in 2019. - Ornis Hungarica 28(1): 1-10. DOI: 10.2478/orhu-2020-0001

local branches and volunteers of the society and national park directorates.

Altogether 5,018 nests and 2,358 White Stork nest holders without nest material were reported. $89.2 \%$ of occupied nests were built on electric poles. Although 80 years ago every third nests were found on trees, in 2019, only 6 were reported at that location. Successful pairs raised 2.62 nestlings on average, breeding success for all breeding pairs was 2.19 , which is lower than typical, probably due to chilly and rainy weather during the breeding season. Based on 3,540 reported breeding pairs and former census data, the White Stork population of Hungary is estimated to be $3,860-4,020$ pairs in 2019. The size of the population was ca. 15-16 thousand pairs in 1941, which halved by 1958 and decreased to 5 thousand pairs by the late 1960s. For four decades, the population fluctuated between 4,800 and 5,500 pairs but in the last twenty years, the number of breeding pairs slightly decreased in the country. The population decline is stronger in hilly areas of W Hungary, i.e. in Somogy, Vas and Zala counties is about $60 \%$.

Keywords: White Stork, national census, breeding population, decrease

Összefoglalás 2019-ben zajlott le a 14. országos fehér gólya felmérés, amelyet a Magyar Madártani és Természetvédelmi Egyesület (MME) szervezett a helyi csoportjai és egyes nemzetipark-igazgatóságok bevonásával. Összesen 5018 fészekről és 2358 fészekanyag nélküli üres fészektartóról küldtek jelentést a felmérők. A fészkek többsége $(89,2 \%)$ villanyoszlopon épült. Bár nyolcvan éve még a fészkek harmada fán volt, 2019-ben már csak 6 db lakott fészket találtak ilyen helyen. Az átlagos fiókaszám az összes költőpárra számolva 2,19, a sikeres párokra számolva 2,62 volt. Ez a jellemző értéknél alacsonyabb költési siker valószínüleg a hủvös, esős május-júniusi időjárásnak köszönhetö.

A jelentésekben szereplö 3540 fészkelö pár és a korábbi cenzusok adatainak összevetésével a teljes hazai költőállományt 3860-4020 pár közé becsüljük. Az állomány 1941-ben 15-16 000 pár lehetett, ami 1958-ra megfeleződött, az 1960-as évek végére pedig még tovább, 5000 pár körülire csökkent. Négy évtizedig 4800 és 5500 pár között fluktuált a fészkelő párok száma, de az elmúlt két évtizedben ismét csökkenést tapasztalhattunk. Ez a csökkenés Nyugat-Magyarország dombvidékein, Somogy, Vas és Zala megyében a legerősebb, akár $60 \%$ is lehet.

Kulcsszavak: fehér gólya, országos felmérés, költőállomány, csökkenés

MME/BirdLife Hungary 1121 Budapest, Költö utca 21., Hungary

*corresponding author, e-mail: lovaszi.peter@mme.hu 


\section{Introduction}

The $14^{\text {th }}$ national White Stork (Ciconia ciconia) census was organised in Hungary after 1941, 1958, 1963, 1968, 1974, 1979, 1984, 1989, 1994, 1999, 2004, 2009 and 2014. Former national census results were published by Homonnay (1964), Marián (1962, 1968, 1971), Jakab (1978, 1985, 1987, 1991), Lovászi (1998, 2004) and Lovászi et al. (2013, 2016). The White Stork population was estimated to be 15-16 thousand pairs in 1941, which halved by 1958. After a further decrease the population stabilized by the late 1960 s and fluctuated between 4,800 and 5,500 pairs. At the last census (2014), we found 4,750-4,950 breeding pairs but strong decrease was detected in West Hungary. Results of regional censuses in the intervening years suggest that this decline is a long-term process and not only a fluctuation of the population as in the last decades. A country-wide nest count was able to answer if the population still stable (fluctuating) or decreasing in total.

\section{Materials and methods}

The census was organised by MME/BirdLife Hungary involving volunteers and national park directorate workers. Nest count was locally organised by county level coordinators, mainly local MME/BirdLife Hungary Groups.

Participants collected the following data of nests and nesting sites: locality (settlement, address, coordinates), nest features (nest holder base, type of electric pole, thickness of the nest, existence and condition of nest holder), occupancy, breeding success (number of nestlings), other information (dangerous electric poles, mortality cases, remarks).

Data were uploaded to the online stork database of MME Monitoring Centre (www.golya. mme.hu).

Data were summarized for counties and settlements. As we had no data for all settlements, missing values were imputed for each settlement to estimate the whole population, based on former census data of given settlement and regional trends.

\section{Results}

The online White Stork database included 12,963 nesting places (nests and metal nest-holders without nest material) at $23^{\text {rd }}$ of February 2020, from which 1,869 was eliminated before 2019, 89 in 2019. The remaining 11,005 locality included 3,907 nesting places (metal nest holder facility) without nest material and 7,098 nests. Data were sent on 2,358 nesting places and 5,018 nests.

Most of the nests were occupied on electric poles (83.7\%) or other poles independent from the electric network (8.8\%). Buildings held $6.2 \%$ of nests, trees only $0.2 \%$ and other sites $0.9 \%$ (Figure 1, Table 1). Other sites were concrete wall (1), wood pile (1), well-pole (1), loudspeaker pole (1), church (1), castle ruin (1), water tank (1), ventilation chimney (2), aviary (4), grain silo (6), and siren pole (12). 


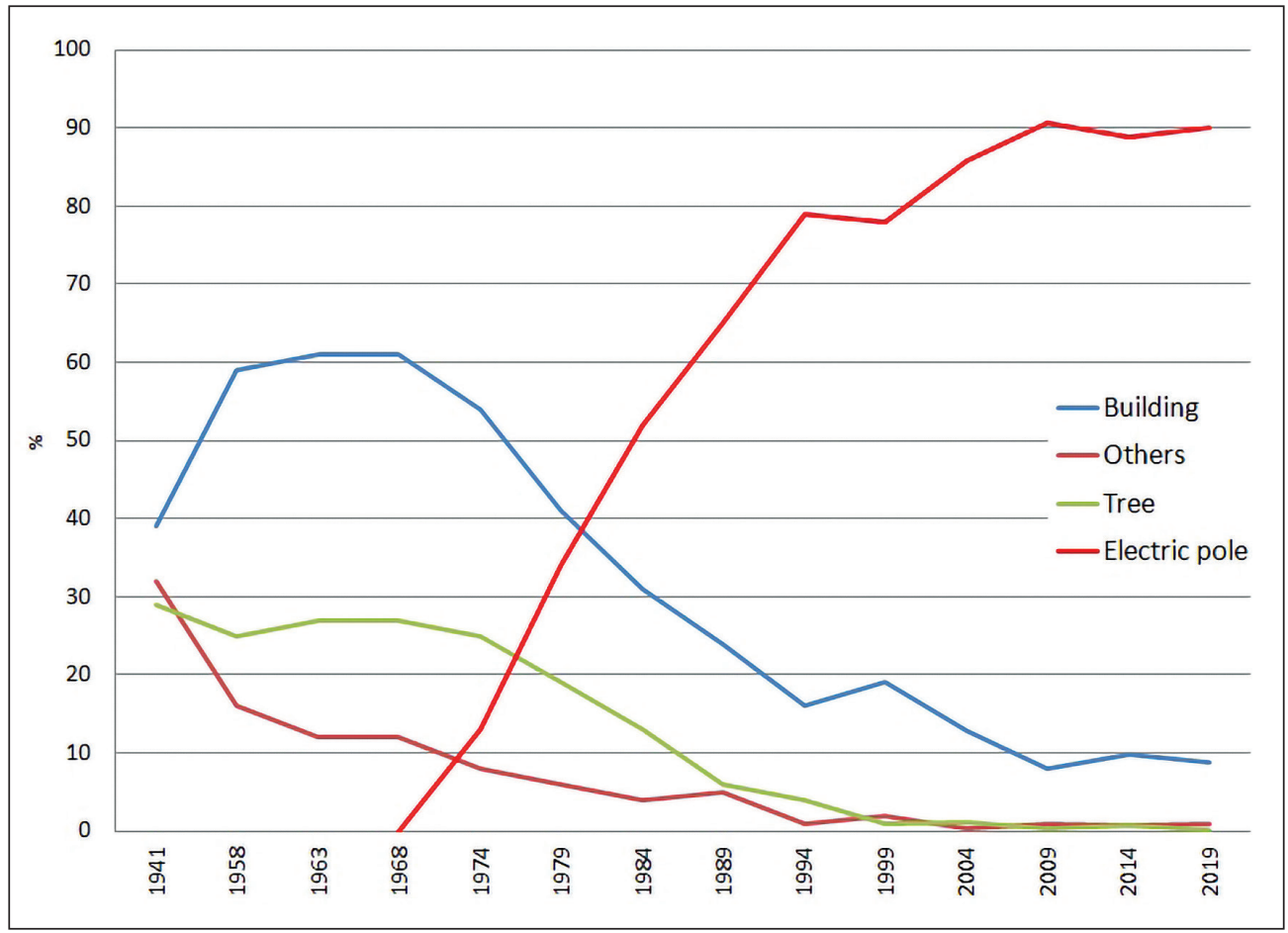

Figure 1. Changes of White Stork nest basements, 1941-2019

1. ábra Fészekaljzatok változása, 1941-2019

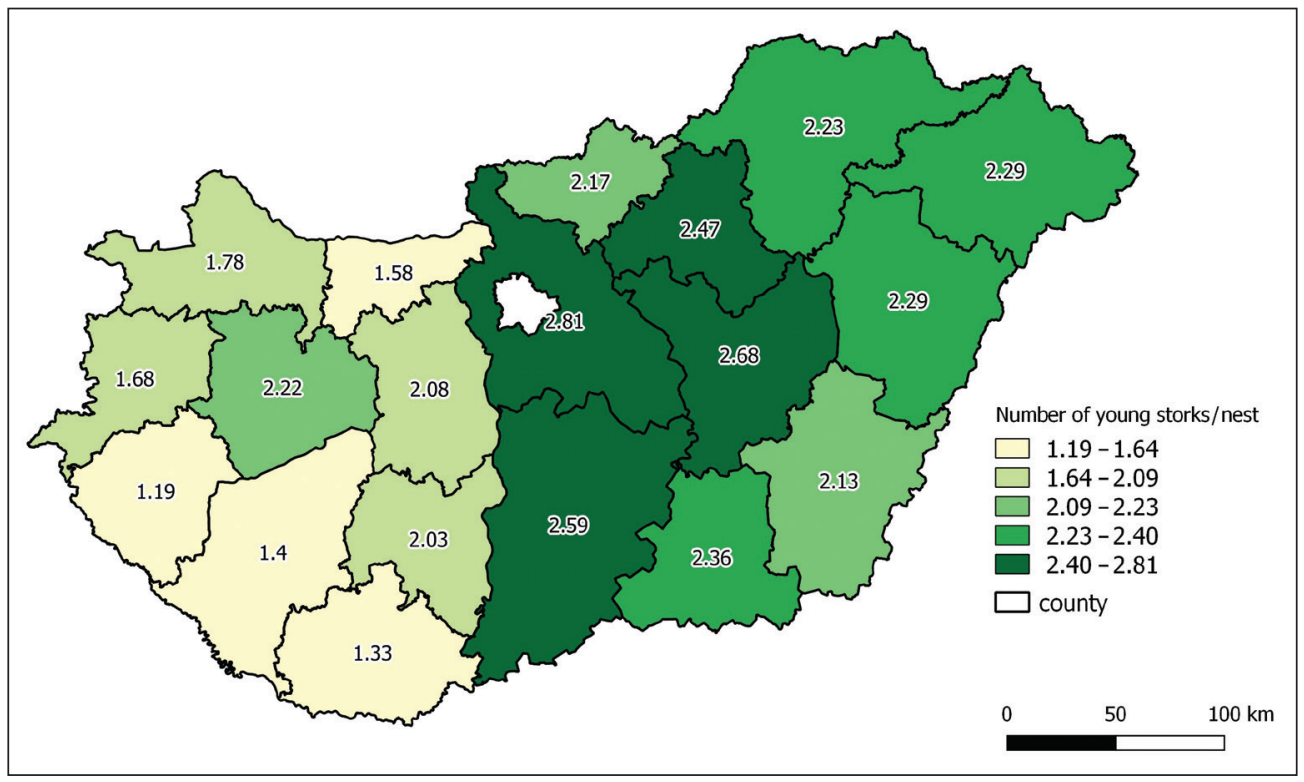

Figure 2. Average number of nestlings/nest (JZa) in counties

2. ábra Átlagos fészkenkénti fiókaszám megyénkénti megoszlása 


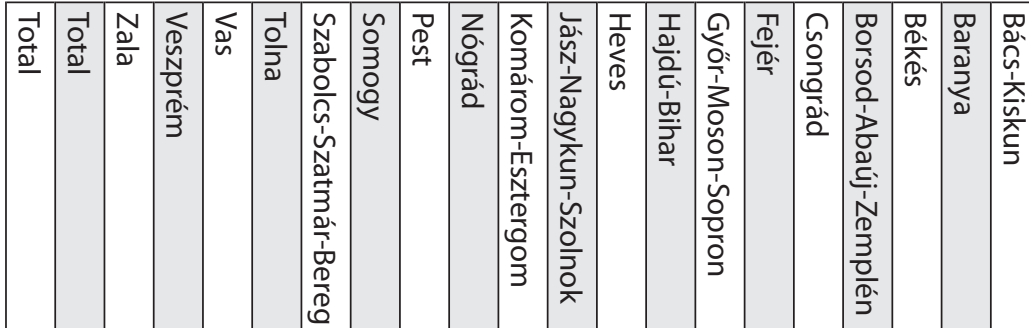

$\stackrel{\wp}{\stackrel{\overbrace{}}{*}}$

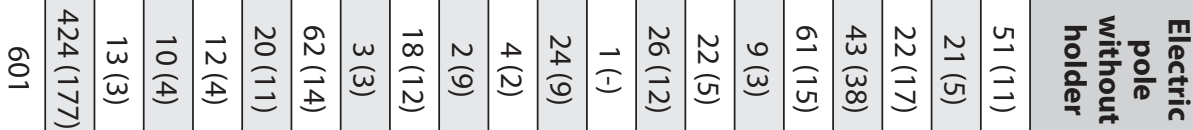

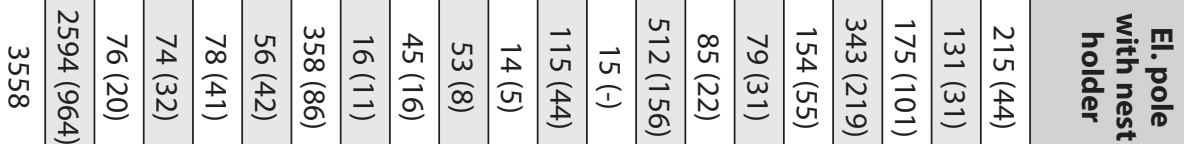

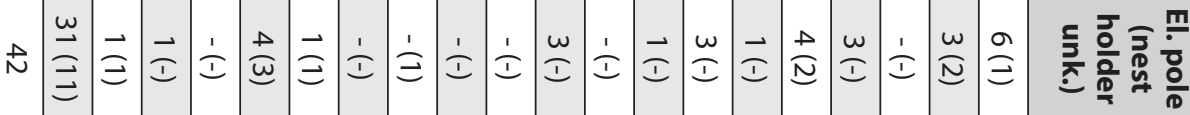

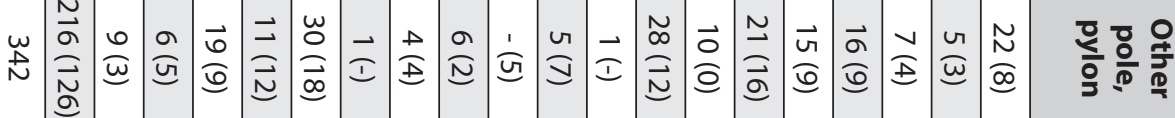

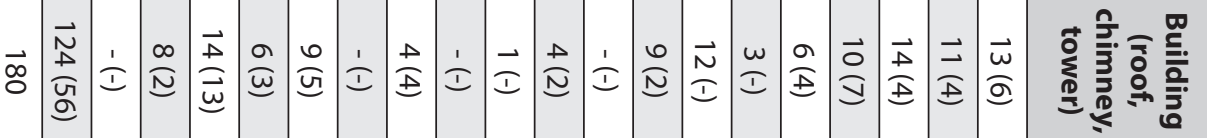

$\frac{2}{2}$
$\vec{a} \frac{2}{9}$
$\vec{a}$

$\left.\frac{1}{5}\right)^{5}$

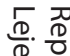

要

$\stackrel{9}{\rightrightarrows} \stackrel{2}{7}$

$\overrightarrow{\mathrm{D}} . \overrightarrow{\mathrm{D}}$

N

출

웃

疍

은

竞

بُ

家

$\stackrel{\frac{0}{\partial}}{\frac{1}{丂}}$

蛋

商

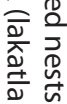

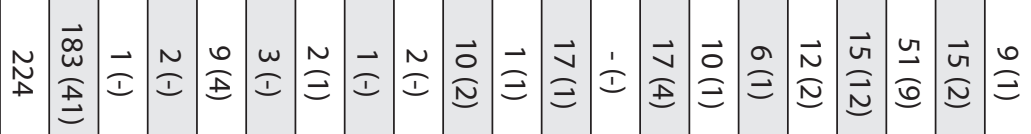

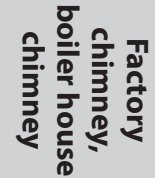

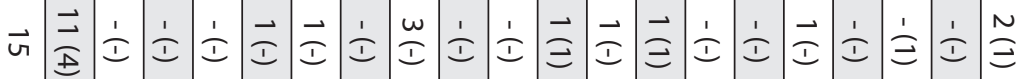

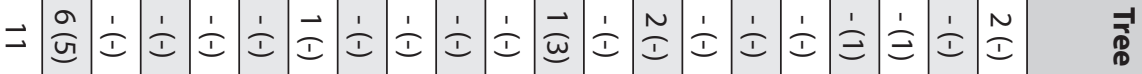

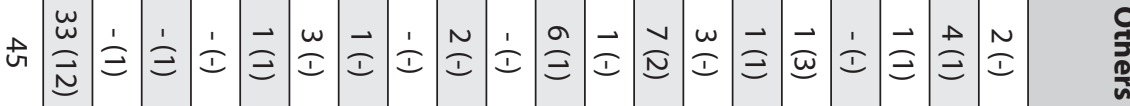

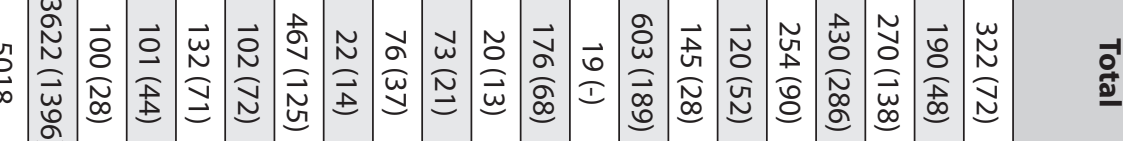

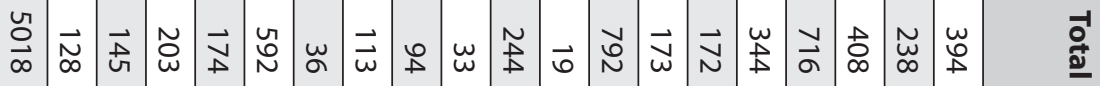


Table 2. Breeding results (HO: unoccupied nest, HE: lonely stork, HPo: unsuccessful pair without fledged nestling, HPm: successful pair, HPa: all breeding pairs)

2. táblázat Költési eredmények (HO: lakatlan fészek, HE: magányos gólya, HPo: sikertelen pár kirepült fióka nélkül, HPm: sikeres pár, HPa: összes költőpár)

\begin{tabular}{|l|c|r|r|r|r|r|r|c|}
\hline \multicolumn{1}{|c|}{ County } & $\begin{array}{c}\text { Empty nest } \\
\text { holder }\end{array}$ & $\begin{array}{c}\text { Nest } \\
\text { attempt }\end{array}$ & HO & HE & HPo & HPm & $\begin{array}{c}\text { HPa - } \\
\text { reported }\end{array}$ & $\begin{array}{c}\text { HPa - total } \\
\text { estimated }\end{array}$ \\
\hline Bács-Kiskun & 44 & 3 & 69 & 6 & 39 & 277 & 316 & $346-366$ \\
\hline Baranya & & & 48 & 3 & 74 & 113 & 187 & 187 \\
\hline Békés & 27 & & 138 & 7 & 49 & 214 & 263 & 263 \\
\hline Borsod-Abaúj-Zemplén & 393 & 26 & 260 & 4 & 83 & 343 & 426 & $470-500$ \\
\hline Csongrád & 102 & 2 & 88 & 6 & 36 & 212 & 248 & 248 \\
\hline Fejér & 126 & & 52 & 1 & 19 & 100 & 119 & 119 \\
\hline Győr-Moson-Sopron & 5 & & 28 & 4 & 39 & 102 & 141 & 141 \\
\hline Hajdú-Bihar & 611 & 3 & 186 & 22 & 40 & 541 & 581 & $589-610$ \\
\hline Heves & & & & & 1 & 18 & 19 & $60-90$ \\
\hline Jász-Nagykun-Szolnok & 146 & 5 & 63 & 2 & 15 & 159 & 174 & $220-270$ \\
\hline Komárom-Esztergom & 1 & & 13 & 1 & 6 & 13 & 19 & 19 \\
\hline Nógrád & 132 & 17 & 4 & 1 & 12 & 60 & 72 & 72 \\
\hline Pest & 37 & 5 & 32 & 1 & 8 & 67 & 75 & $105-115$ \\
\hline Somogy & 14 & 5 & 9 & 2 & 8 & 12 & 20 & $120-200$ \\
\hline $\begin{array}{l}\text { Szabolcs-Szatmár- } \\
\text { Bereg }\end{array}$ & 455 & 7 & 118 & 8 & 72 & 387 & 459 & $489-494$ \\
\hline Tolna & 2358 & 73 & 1323 & 82 & 588 & 2952 & 3540 & $3907-4184$ \\
\hline Vas & 174 & & 71 & 2 & 32 & 98 & 130 & $130-135$ \\
\hline Veszprém & 31 & & 44 & 6 & 12 & 83 & 95 & 95 \\
\hline Zala & 6 & & 28 & 4 & 24 & 72 & 96 & $134-160$ \\
\hline Total & & & 72 & 2 & 19 & 81 & 100 & 100 \\
\hline
\end{tabular}

Out of the 5,018 reported nest, there were 73 nest attempt (1.5\%), 1,323 unoccupied nests $(26.4 \%), 82$ lonely White Stork (1.6\%), 588 unsuccessful pairs (11.7\%) and 2,952 successful pairs with nestlings (58.8\%) (Table 2).

Successful pairs typically raised 3 or 4 nestlings. Breeding success was 2.19 , calculated for all pairs, 2.62 for successful pairs (Table 3). Breeding success varied between 1.19 and 2.81 in certain counties (Figure 2).

Most White Storks bred in NE Hungary (Borsod-Abaúj-Zemplén, Hajdú-Bihar and Szabolcs-Szatmár-Bereg counties), 1,550-1,600 pairs, which is about $40 \%$ of the country's population. The density is the highest near rivers (especially in the Upper Tisza valley) and around large wet or saline grasslands (like Hortobágy). White Storks do not breed in mountain areas (ca. $500 \mathrm{~m}$ above sea level), in the Budapest agglomeration and large monocultural plough lands (Figure 3). 
Table 3. Breeding success (JZG: total number of nestlings fledged, JZa:average number of nestlings for all nests, JZm: average number of nestlings for successful nests)

3. táblázat Költési siker (JZG: kirepült fiókák száma, JZa: összes költőpár fészkenkénti fiókaátlaga, JZm: sikeres párok fészkenkénti fiókaátlaga)

\begin{tabular}{|c|c|c|c|c|c|c|c|c|}
\hline \multirow{2}{*}{ County } & \multicolumn{5}{|c|}{ Number of nestlings } & \multirow{2}{*}{ JZG } & \multirow{2}{*}{ JZa } & \multirow{2}{*}{$J Z m$} \\
\hline & 1 & 2 & 3 & 4 & 5 & & & \\
\hline Bács-Kiskun & 15 & 56 & 127 & 69 & 7 & 819 & 2.59 & 2.96 \\
\hline Baranya & 34 & 34 & 33 & 12 & - & 249 & 1.33 & 2.20 \\
\hline Békés & 32 & 63 & 68 & 48 & 1 & 559 & 2.13 & 2.61 \\
\hline Borsod-Abaúj-Zemplén & 38 & 93 & 125 & 77 & 9 & 952 & 2.23 & 2.78 \\
\hline Csongrád & 13 & 42 & 101 & 40 & 5 & 585 & 2.36 & 2.76 \\
\hline Fejér & 13 & 31 & 44 & 10 & - & 247 & 2.08 & 2.47 \\
\hline Győr-Moson-Sopron & 15 & 37 & 38 & 12 & - & 251 & 1.78 & 2.46 \\
\hline Hajdú-Bihar & 22 & 82 & 146 & 154 & 18 & 1330 & 2.29 & 2.46 \\
\hline Heves & 3 & 4 & 8 & 3 & - & 47 & 2.47 & 2.61 \\
\hline Jász-Nagykun-Szolnok & 12 & 33 & 64 & 39 & 8 & 466 & 2.68 & 2.93 \\
\hline Komárom-Esztergom & 3 & 4 & 5 & 1 & - & 30 & 1.58 & 2.31 \\
\hline Nógrád & 10 & 18 & 18 & 14 & - & 156 & 2.17 & 2.60 \\
\hline Pest & 2 & 10 & 31 & 19 & 4 & 211 & 2.81 & 3.15 \\
\hline Somogy & 2 & 5 & 4 & 1 & - & 28 & 1.40 & 2.33 \\
\hline Szabolcs-Szatmár-Bereg & 56 & 95 & 142 & 84 & 9 & 1053 & 2.29 & 2.72 \\
\hline Tolna & 15 & 23 & 30 & 13 & - & 203 & 2.03 & 2.51 \\
\hline Vas & 19 & 45 & 28 & 4 & 2 & 219 & 1.68 & 2.23 \\
\hline Veszprém & 7 & 31 & 36 & 6 & 2 & 211 & 2.22 & 2.54 \\
\hline Zala & 12 & 23 & 16 & 2 & - & 114 & 1.19 & 1.58 \\
\hline Total Hungary & 323 & 729 & 1064 & 608 & 65 & 7730 & 2.19 & 2.62 \\
\hline
\end{tabular}

More than 20 pairs occupied nest in Nádudvar (33), Hortobágy (30), Komádi (28), Egyek (27), Görbeháza (27), Berettyóújfalu (25), Sárospatak (25), Akasztó (24), Balmazújváros (24), Mezőcsát (23), Nagyiván (22), Szeghalom (21) settlements (Figure 4).

Unlike Poland, where White Storks breed mainly in settlements with less than 100 thousand inhabitants (Kopij 2017), in Hungary, several cities has considerable population, like Nyíregyháza (12), Szeged (11) and Debrecen (10) cities. However, aggregation of White Storks around landfills reported from several countries (e.g. Bialas et al. 2020) was not reported yet from Hungary. 


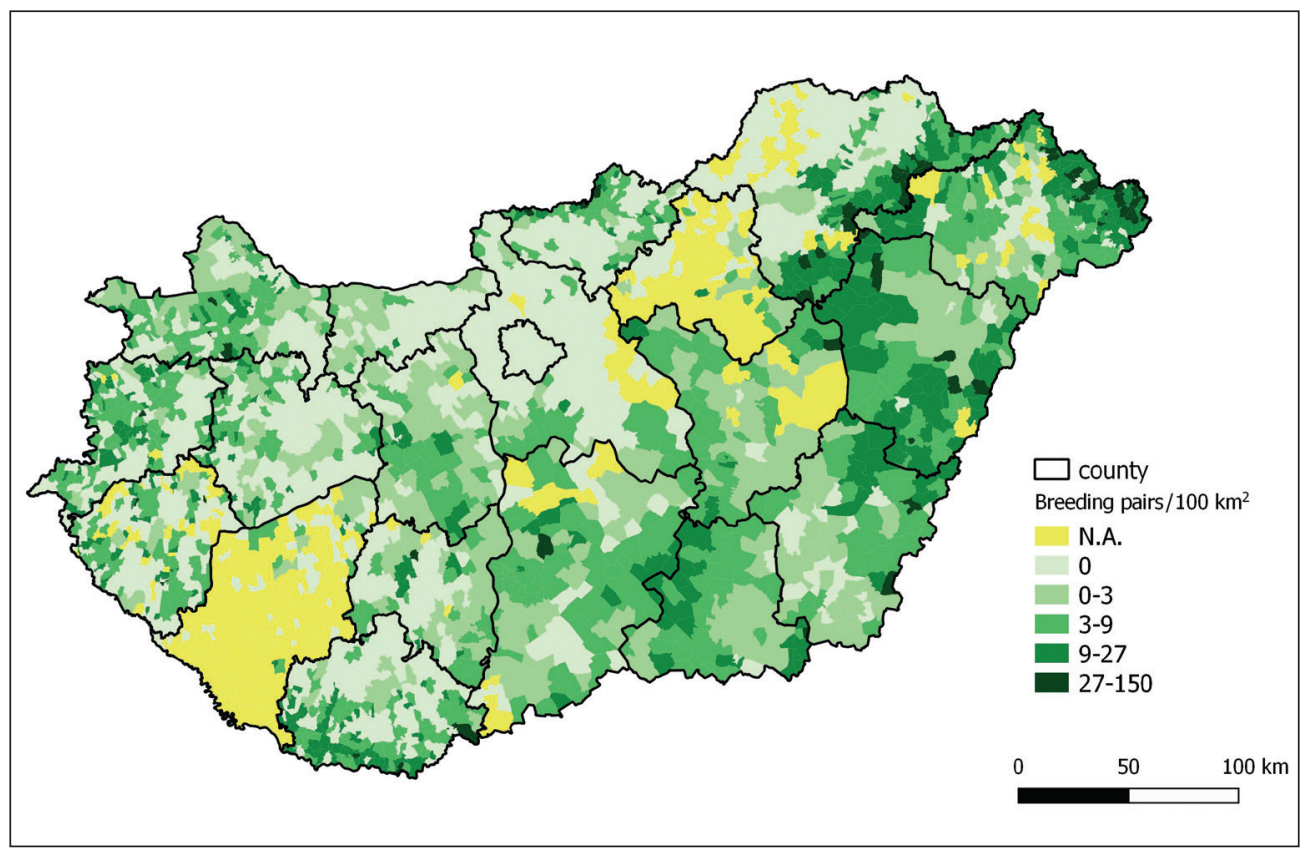

Figure 3. Density of breeding pairs for settlement's administrative boundaries (pair/100 km²) 3. ábra Költőpárok sűrűsége település közigazgatási határonként (pár/100km²)

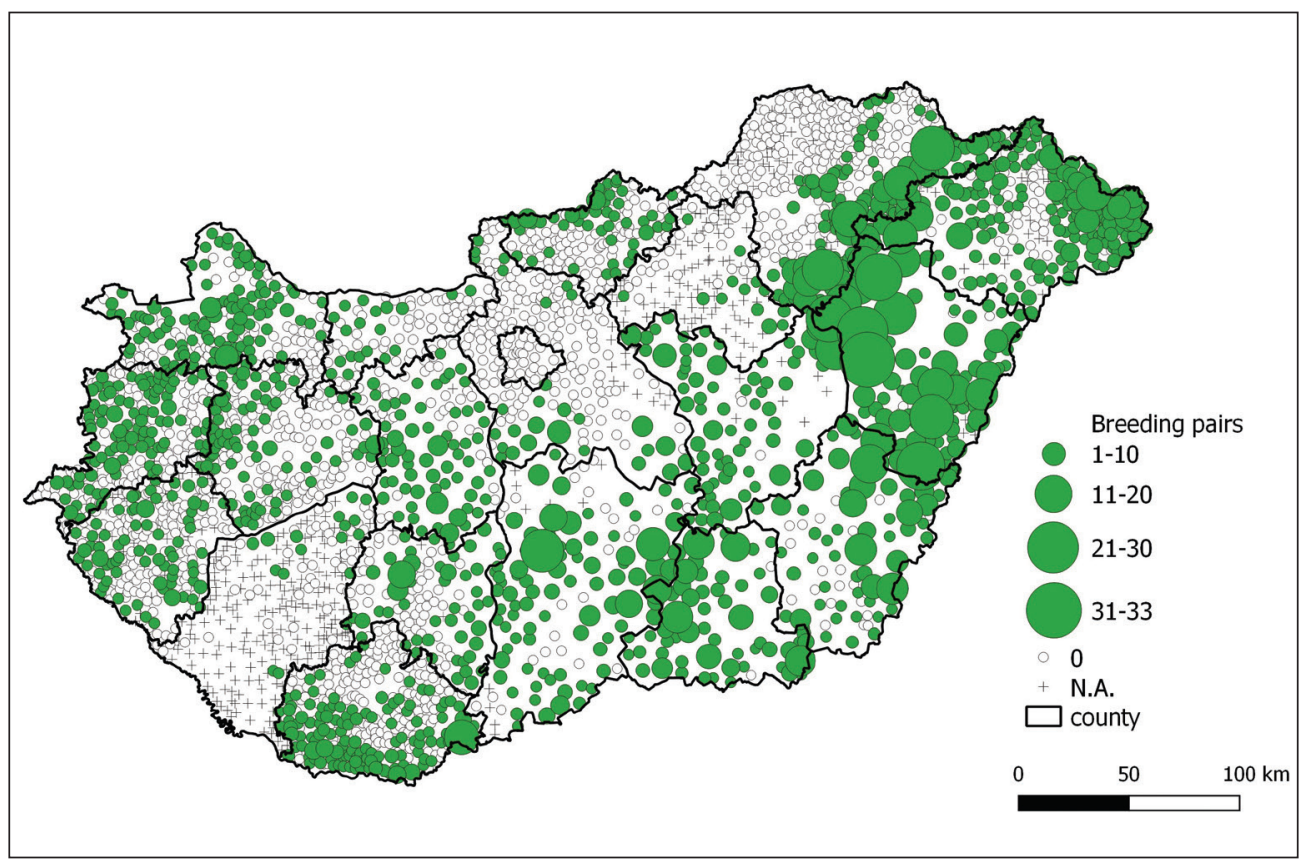

Figure 4. Number of breeding pairs in settlements 4. ábra Költőpárok száma településenként 


\section{Discussion}

\section{Breeding sites}

First White Stork nests placed to electric poles were reported in 1968. Occupation of new nesting basement took place at the same rate in different parts of the country (Gyalus et al. 2018). By 1994, altogether $79 \%$ of nests were found on electric network or other pylons and it was amounted to a maximum of $90.6 \%$ in 2009. Almost the same number of nests were found on buildings and other places in the last 15 years but trees seems disappearing: while every $3^{\text {rd }}$ nest were built on trees in the 1940s (Homonnay 1964), in 2019, only 6 were occupied by White Storks.

\section{Breeding success}

Breeding success varied between 1.58 and 3.09 since 1958 on a country-wide level, average was 2.34 nestlings for all breeding pairs. In 2019, only 2.19 young White Stork fledged from a nest on average due to frequent rains and colder temperature in May and June. The number of nestlings were lower in W Hungary (Baranya, Györ-Moson-Sopron, Komárom-Esztergom, Vas, Zala counties), where population loss is the highest. As new breeder, young birds tend to settle in the vicinity of their natal site (Chernetsov et al. 2006), further regional shrinking may occur.

\section{Population changes}

Although the eastern core populations (Poland, the Baltic States, Belarus, Ukraine) of White Storks counted more than 90 thousand and the southern (Iberian) population was 20 thousand breeding pairs in 2004 (Thomsen 2013), the much smaller Hungarian population is also a considerable part of the population of the species. The national population - similarly to other areas - suffered a significant loss in the $20^{\text {th }}$ century.

The breeding site and habitat selection of the White Stork depends on suitable nest basements and feeding areas. The density is negatively influenced by several factors, like elevation, cover of shrublands and forests, and positively influenced by the presence of wetlands, grasslands, number of grazing animals (Carrascal et al. 1993, Wojciechowski \& Janiszewski 2006, Tryjanowski et al. 2009, Radovic et al. 2015). In Hungary due to loss of traditional nest sites (wide chimneys, old trees, traditional hay stacks), loss and degradation of feeding sites (plowing grasslands, drainage, intensification), decrease of the population was caused. The decline of the population stopped when birds started to use electric poles as nesting sites (Lovászi 2013). From the 1970s, nature conservation and electric companies mounted hundreds of metal nest holders onto electric poles. As a result of this controversial help, $90 \%$ of White Storks mowed to electric poles. As standards of wiring change nowadays, new networks are built of isolated single cables instead of parallel uninsulated metal wires and older ones are also under change to following new standard, White Storks cannot built (or much more less) new nests to electric poles what can lead to further loss of pairs. 
We do not know effect of climate change on breeding success. Weather of the Carpathian basin is influenced by Mediterranean, Atlantic and Continental climate zones, causing very variable temperature and rainfall distribution between years and seasons. Annual rainfall varies between about 400 and $800 \mathrm{~mm}$, decreasing by $10 \%$ in the last hundred years (OMSZ 2020). These changes are unfavourable as White Storks primarily use wet or temporary wet grasslands, marshes. The national park directorates made several small and medium scale wetland revitalisations but these habitats hold only a small proportion of the population.

Above mentioned changes may adumbrate further loss of breeding White Stork population of Hungary. Unfortunately, actual population data are not available on international level. Latest reporting under Article 12 of the EU's Birds Directive provides national data from the 2008-2012 period (https://www.eionet.europa.eu/etcs/etc-bd/activities/reporting/ article-12/art-12-reporting-2008-2012), also reporting decreasing population in neighbouring Austria and Slovakia.

\section{Acknowledgements}

In the last years, several hundreds of professional conservationists and volunteer birdwatchers, organisations uploaded data to MME's White Stork database. It is impossible to mention all of them but we thank for all the help of them. Regional coordinators were or large amount of nests were reported by Péter Balázsi, László Bank, Gellért Bátky, Szabolcs Gál, Zoltán Görögh, Előd Győrig, Béla Habarics, Attila Hankóczi, Péter Homoki, Péter Hunyadvári, Balázs Forgách, Tibor Juhász, András Kóta, Csaba Lendvai, Péter Lovászi, Károly Nagy, Sándor Nagy, Ferenc Papp, Ferenc Polyák, József Serfőző, István Staudinger, Ernő Szelle, Ottó Veszelinov and Hortobágy National Park Directorate and Kiskunsági National Park Directorate.

\section{References}

Bialas, J. T., Dylewski, Ł. \& Tobolka, M. 2020. Determination of nest occupation and breeding effect of the White Stork by human-mediated landscape in Western Poland. - Environmental Science and Pollution Research 27: 4148-4158. DOI: 10.1007/s11356-019-06639-0

Carrascal, L. M., Bautista, L. M. \& Lázaro, E. 1993. Geographical variation in the density of the White Stork Ciconia ciconia in Spain: Influence of habitat and climate. - Biological Conservation 65: 83-87. DOI: 10.1016/0006-3207(93)90200-K

Chernetsov, N., Chromik, W., Dolata, P. T., Profus, P. \& Tryjanowski, P. 2006. Sex-related natal dispersal of White Storks (Ciconia ciconia) in Poland: How far and where to? - The Auk 123(4): 1103-1109. DOI: 10.1093/ auk/123.4.1103

Gyalus, A., Végvári, Zs. \& Csörgő, T. 2018. Changes in the nest sites of White Stork (Ciconia ciconia) in Hungary. - Ornis Hungarica 26(1): 65-88. DOI: 10.1515/orhu-2018-0005

Homonnay, N. 1964. Magyarország és környezö területei gólyaállományának mennyiségi felvételezése az 1941. évben [Results of White Stork census in Hungary and surrounding territories in 1941]. - Aquila 69-70: 83102. (in Hungarian)

Jakab, B. 1978. Magyarország gólyaállományának 1974. évi felmérése [Census of White Stork population of Hungary in 1974.]. - Móra Ferenc Múzeum Évkönyve 1976/77(1): 495-534. (in Hungarian)

Jakab, B. 1985. A gólya populációdinamikájának két évtizede az 1979. évi felmérés eredményeinek tükrében Magyarországon [Population dynamics of two decades of White Storks in the light of census in 1979.]. Móra Ferenc Múzeum Évkönyve 1982-83(1): 413-451. (in Hungarian) 
Jakab, B. 1987. A fehér gólya állománya Magyarországon 1984-ben [Population of the White Stork in Hungary in 1984]. - Móra Ferenc Múzeum Évkönyve 1987(1): 473-512. (in Hungarian)

Jakab, B. 1991. Az 1989. évi gólyaszámlálás értékelése [Evaluation of the White Stork Census in 1989]. - Madártani Tájékoztató 1991(1-2): 3-4. (in Hungarian).

Kopij, G. 2017. Changes in the number of nesting pairs and breeding success of the White Stork Ciconia ciconia in a large city and a neighbouring rural area in South-West Poland. - Ornis Hungarica 25(2): 109-115. DOI: 10.1515/orhu-2017-0018

Lovászi, P. 1998. A fehér gólya Ciconia ciconia helyzete Magyarországon az 1941-1994 közötti országos állományfelmérések tükrében [Status of the White Stork (Ciconia ciconia) in Hungary: results of national censuses between 1941-1994]. - Ornis Hungarica 8(Suppl.1): 1-8. (in Hungarian with English Summary)

Lovászi, P. 2004. A fehér gólya Ciconia ciconia helyzete Magyarországon, 1941-2002 [Status of the White Stork Ciconia ciconia in Hungary, 1941-2002]. - Aquila 111: 11-18. (in Hungarian with English Summary)

Lovászi, P., Nagy, K. \& Lendvai, Cs. 2013. Results of the White Stork Ciconia ciconia census in Hungary in 2004. - In: Thomsen, K-M. \& Lachman, L. (eds.) White Stork populations across the world. - Results of the $6^{\text {th }}$ International White Stork census 2004/2005. NABU, Berlin, pp. 25-26.

Lovászi, P., Lendvai, Cs. \& Nagy, K. 2016. Results of the 2014 national White Stork Ciconia ciconia census in Hungary. - Aquila 122-123: 47-56.

Lovászi, P. 2013. Fehér gólya Ciconia ciconia fajmegőrzési terv [White Stork Ciconia ciconia Species Action Plan]. - VM Környezetügyért Felelős Államtitkárság, Budapest (in Hungarian)

Marián, M. 1962. Der Weißstorch in Ungarn in dem Jahre 1956-1958. [The White Stork in Hungary between 1956-1958]. - Móra Ferenc Múzeum Évkönyve 1960(2): 231-269. (in German)

Marián, M. 1968. Bestandsveranderung beim Weiss-storch in Ungarn 1958-1963 [Change of population of the White Stork in Hungary 1958-1963]. - Móra Ferenc Múzeum Évkönyve 1968: 283-314. (in German)

Marián, M. 1971. A gólya populáció-dinamikája Magyarországon 1963-1968. [Population dynamics of the White Stork in Hungary 1963-1968]. - Móra Ferenc Múzeum Évkönyve 1971(1): 37-72. (in Hungarian with German Summary)

OMSZ 2020 Magyarország csapadék viszonyai [Precipitation conditions in Hungary]. - https://www.met.hu/ eghajlat/magyarorszag_eghajlata/altalanos_eghajlati_jellemzes/csapadek/ (Accessed on 28 April 2020) (in Hungarian)

Radovic, A., Kati, V., Tadic, M. P., Denac, D. \& Kotrosan, D. 2015. Modelling the spatial distribution of White Stork Ciconia ciconia breeding populations in Southeast Europe. - Bird Study 2014: 1-9. DOI: $10.1080 / 00063657.2014 .981502$

Thomsen, M-K. 2013. Results of the $6^{\text {th }}$ International White Stork Census 2004/2005. - In: Thomsen, K-M. \& Lachman, L. (eds.) White Stork populations across the world. - Results of the $6^{\text {th }}$ International White Stork Census 2004/2005. NABU, Berlin, pp. 25-26.

Tryjanowski, P., Leszek, J. \& Radkiewicz, J. 2009. Effect of water level and livestock on the productivity and numbers of breeding White Storks. - Waterbirds 28: 378-382. DOI: 10.1675/1524-4695(2005)028[0378:EOWLAL]2.0.CO;2.

Wojciechowski, Z. \& Janiszewski, T. 2006. The effect of biotopic conditions on the density of a White Stork population in Central Poland. - In: Tryjanowski, P., Sparks, T. H. \& Jerzak, L. (eds.) The White Stork in Poland: studies in biology, ecology and conservation. - Bogucki Wydawnictwo Naukowe, Poznań

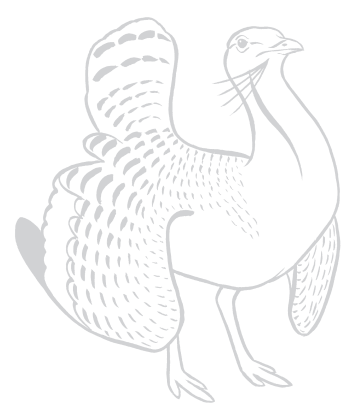

